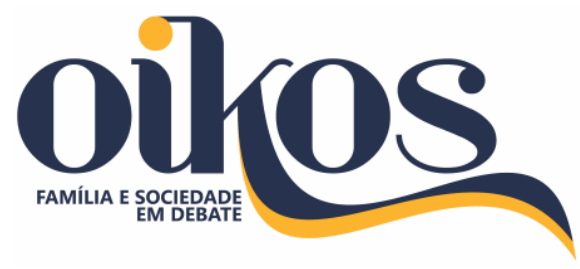

CARMO, Nilva Celestina; LORETO, Maria das Dores Saraiva; CORCETTI, Elisabete; RODRIGUES, Fabíola Faria da Cruz. Repercussões do Programa Mulheres Mil nas trajetórias de vidas femininas: uma análise textual. Oikos: Família e Sociedade em Debate, v. 29, n. 2, p. 278-306, 2018.

DOI: https://doi.org/10.31423/oikos.v29i2.3804

PPGED

Programa de Pós-Graduação em Economia Doméstica

\title{
Repercussões do Programa Mulheres Mil nas trajetórias de vidas femininas: uma análise textual ${ }^{1}$
}

\section{Repercussions of the Programa Mulheres Mil in the female living trajectories: a textual analysis}

\author{
Nilva Celestina Carmo² \\ Maria das Dores Saraiva Loreto ${ }^{3}$ \\ Elisabete Corcetti ${ }^{4}$ \\ Fabíola Faria da Cruz Rodrigues ${ }^{5}$
}

\section{Resumo}

A economia brasileira vem passando por mudanças, que induzem à implantação de políticas públicas inclusivas e, dentre essas ações, insere-se 0 Programa Mulheres Mil (PMM). Evidências empíricas têm questionado a eficácia dessas políticas, em função da sua focalização e fragmentação. Nesta pesquisa, objetivou-se analisar a repercussão do PMM na trajetória de vida das mulheres. A pesquisa, realizada nos municípios de Barbacena e Barroso, em Minas Gerais e nas cidades de Vitória, Guarapari e Colatina, no Espírito Santo, pautou-se em dados bibliográficos e documentais, bem como em entrevistas semiestruturadas, cujos dados foram examinados pela análise de conteúdo e textual, com - apoio do software IRaMuTeQ (Interface de $R$ pourles Analyses Multidimensionnelles de Texteset de Questionnaires). Os resultados evidenciaram que - PMM apresenta limitações no enfrentamento da exclusão social feminina, com poucas mudanças no nível educacional e baixa inserção no mercado laboral; embora seja reconhecido, na percepção das mulheres, como-fato marcante em suas trajetórias de vida, proporcionando melhoria da autoestima, motivação e integração social.

Palavras-chave: Política Pública Educacional; PMM; Percurso da vida; Análise lexicográfica.

\begin{abstract}
The Brazilian economy has been undergoing changes, which lead to the implementation of inclusive public policies and, among these actions, the Programa Mulheres Mil (PMM) is inserted. Empirical evidence has questioned the effectiveness of these policies, due to their focus and fragmentation. The objective of this research was to analyze the repercussion of PMM on the life trajectory of women.The research, carried out in Barbacena and Barroso municipalities of Minas Gerais and in the cities of Vitória, Guarapari and Colatina of Espírito Santo, made use of bibliographical and documentary research, as well as semi-structured interviews, whose data were examined by content analysis and with the support of IRaMuTeQ (Interface de $R$ pourles Analyses Multidimensionnelles de Texteset de Questionnaires) software. The results showed that the PMM has limitations in facing female social exclusion, with few changes in the educational level and low insertion in the labor market; although it is recognized in the perception of women as a remarkable fact in their life trajectories, providing improvement of selfesteem, motivation and social integration.
\end{abstract}

Keywords: Public Educational Policy; PMM, Life course; Lexicographic analysis

\footnotetext{
1 O presente trabalho foi realizado com apoio do Conselho Nacional de Desenvolvimento Científico e Tecnológico - Brasil (CNPQ).

${ }^{2}$ Mestranda em Economia Doméstica pela Universidade Federal de Viçosa (UFV). Professora de Ensino Básico, Técnico e Tecnológico do Instituto Federal do Sudeste de Minas Gerais (IFSUDESTE MG) - Campus Rio Pomba. E-mail: nilva.carmo@ifsudestemg.edu.br

${ }^{3}$ Doutora em Economia Rural pela Universidade Federal de Viçosa (UFV). Professora do Programa de Pós-Graduação em Economia Doméstica da Universidade Federal de Viçosa (UFV). E-mail: mdora@ufv.br

${ }^{4}$ Doutora em Economia Doméstica pela Universidade Federal de Viçosa (UFV). Professora do Instituto Federal de Educação do Espírito Santo (IFES). E-mail: tutortcc.elisabete@gmail.com

${ }^{5}$ Graduanda em Ciência e Tecnologia de Laticínios pela Universidade Federal de Viçosa (UFV). Bolsista de Iniciação Científica (PIBIC/CNPQ) pelo Departamento de Economia Doméstica da Universidade Federal de Viçosa (UFV). E-mail: fabiolafcrodrigues@gmail.com
} 


\section{INTRODUÇÃO}

A recente desaceleração da economia é comentada por Cury e Silveira (2018), que, baseando-se nas estatísticas do Instituto Brasileiro de Geografia e Estatística (IBGE), evidenciam o pior desempenho conjuntural desde 1990, com reflexos na taxa de desemprego, renda familiar e desigualdades sociais. Esse cenário tem feito com que o governo promova políticas públicas inclusivas, como é o caso do Programa Mulheres Mil (PMM) e daquelas voltadas ao turismo social.

Uma das justificativas para associar o PMM, objeto de estudo da presente pesquisa, com o setor de turismo reside na sua importância para a economia nacional, mesmo diante da crise e mudanças perpassadas. Para Bancillon e Negreiros (2017), nenhum outro setor tem capacidade de gerar tantos empregos e investimentos quanto o do turismo; sobretudo, em momento de crise, com limitada fronteira de crescimento, desigualdades sociais e de gênero.

Braga (2015) corrobora com essa afirmativa, ao destacar que o turismo, no Brasil, representa aproximadamente $9 \%$ do $\mathrm{PIB}$, considerado como parte crescente da economia global. Nessa mesma perspectiva, Pires (2017) ressalta que, no Brasil, mesmo em tempo de instabilidade econômica, o turismo tem se sustentado e tem sido ponto de apoio para a economia nacional. Ainda de acordo com a autora, há dados que demonstram a superação das projeções, no nível de emprego formal para o setor de turismo.

Por outro lado, a associação entre o PMM e as atividades de turismo advém desde a origem do programa, uma vez que o programa iniciou-se, no Brasil, em 2005, na área de turismo e hospitalidade, com um projeto piloto, decorrente da Cooperação Internacional Brasil-Canadá, por meio de parceria entre a Agência Canadense para o Desenvolvimento Internacional (CIDA/ACDI) e a Associação dos Colleges Comunitários do Canadá (ACCC), além dos Colleges parceiros e o Instituto Federal do Rio Grande do Norte (IFRN), na época Centro Federal de Educação Profissional e Tecnológica (CEFET). Como aponta Rosa (2011), esse projeto piloto teve como primeira ação realizada a qualificação de mulheres em atividades turísticas, baseando-se na ARAP (Avaliação e Reconhecimento de Aprendizagem Prévia) do sistema canadense de educação.

Dada a experiência exitosa desse projeto piloto, foi instituído, de 2007 a 2011, o Programa Mulheres Mil (PMM), que tinha como objetivo o desenvolvimento de ações educativas, a partir de cursos de Formação Integrada Continuada (FIC) para mulheres adultas, em treze estados brasileiros, fazendo uso dos seguintes instrumentos metodológicos: a) questionários de acesso; 
b) mapas da vida; e c) portfólios. Em todos esses casos, tais instrumentos serviram como ferramentas que traduziam a linguagem das mulheres e comunidades envolvidas, por meio da oralidade, sendo considerados como memória dos conhecimentos absorvidos durante as capacitações (BRASIL, 2012).

De acordo com as informações apresentadas acima, o PMM articula, portanto, conjunto de ações que buscam consolidar as políticas públicas e diretrizes governamentais de inclusão educacional, social e produtiva de mulheres em situação de vulnerabilidade. O programa possui, portanto, viés de gênero, ao ter como público-alvo mulheres em situação de vulnerabilidade social, moradoras de comunidades integrantes dos territórios da cidadania e, ou, comunidades, com baixo índice de desenvolvimento humano. Focaliza na promoção da formação educacional, profissional e tecnológica, que possibilite mudar a trajetória de vida feminina, por meio da elevação de escolaridade, acesso ao mundo do trabalho, estímulo ao empreendedorismo, economia solidária, empregabilidade e emancipação.

Outra justificativa para a relação do programa com as atividades turísticas pode ser evidenciada no estudo de Lunardi e Almeida (2006), que mostra a expressiva integração do turismo com o segmento feminino, ressaltando que, na percepção das mulheres, o turismo, além de representar uma fonte inovadora de recursos financeiros e de geração de empregos, possui um valor social, pela oportunidade de ampliar seus conhecimentos culturais, melhorar o relacionamento e a interação com o mundo exterior, possibilitar a simultaneidade entre as atividades domésticas e o trabalho profissional, bem como participar de atividades que antes não eram possíveis, como nas associações de turismo. Assim, os autores consideram que essa integração deveria ser incentivada e materializada, por meio de políticas públicas inclusivas, com recorte de gênero.

Conforme Dias e Matos (2012, p.14), entende-se por políticas públicas a gestão dos problemas e demandas coletivas, "através da utilização de metodologias que identificam as prioridades, racionalizando a aplicação de investimentos e utilizando o planejamento como forma de se atingir os objetivos e metas predefinidos". Ou seja, representam as ações e intervenções planejadas pela administração pública; enquanto as políticas públicas educacionais seriam tudo aquilo que o Estado faz ou deixa de fazer em termos de ações educativas.

Nesse sentido, a educação pode ser vista como direito social a que todos deveriam ter acesso, constituindo a porta de entrada para o desenvolvimento das pessoas/comunidades, na medida em que permite aquisição de informação e conhecimentos; aperfeiçoamento de aptidões, qualificação para o mercado de trabalho e aumento da produtividade; democratização da 
estrutura ocupacional, geração de emprego e autonomia; enfim, distribuição mais justa de oportunidades sociais, respeito da dignidade humana e melhoria da qualidade de vida (CAMPOS; RENGIFO; MEZA, 2011).

Canotilho, Araújo e Oliveira (2017) corroboram com esta perspectiva, ao afirmarem que a educação constitui temática relevante para pensar a igualdade de gênero. Na visão das autoras, o princípio mainstreaming exige que as questões de gênero e da igualdade de oportunidades sejam integradas de forma transversal em todas as políticas, tanto nacional quanto setorialmente, sendo a educação profissional uma área fundamental destas políticas.

Dessa forma, tanto no âmbito do PMM quanto do setor de turismo, a educação deve ser priorizada e, em especial, a coeducação ${ }^{6}$, explicitamente considerada como forma de educação que pode contribuir para a eliminação de papéis de gênero e identificação das diferenças de poder entre os sexos, que dão origem a formas de uma cidadania mitigada de mulheres, reduzindo-as à esfera do privado e as limitando do direito de participarem na vida pública.

Assim, o cerne do problema reside no fato de que a educação profissional é um dos principais desafios da economia brasileira e, no setor de turismo, não é diferente. Segundo Macedo (2013), o levantamento do Instituto de Pesquisa Econômica Aplicada (IPEA), realizado em 2012, em parceria com o Ministério do Turismo, demonstrou que o ramo turístico no país enfrenta problemas, como alta rotatividade de funcionários e ausência de políticas internas de incentivo à qualificação do trabalhador.

Dessa forma, apesar dos esforços de diversas instituições para a qualificação no setor do turismo, as ações desenvolvidas demonstram pouca sinergia. Mesmo com os avanços consideráveis, realizados desde 2003, foram obtidos resultados pontuais e descontínuos. Ou seja, no setor ainda persiste predominância de métodos inadequados, que levam a resultados insuficientes no processo de aprendizagem, distanciando a possibilidade de apropriação mais criativa e construtiva dos conteúdos e do contexto de realização do próprio trabalho. Observase, também, a ausência de políticas afirmativas de gênero, etnia e geracional, apesar do alto número de estudantes mulheres e jovens nos cursos da área de turismo. Esta realidade demonstra a necessidade de atendimento, tanto no campo pedagógico quanto no metodológico, mais apropriado às especificidades desses segmentos sociais (BRASIL, 2015).

6 Segundo Almeida, Salazar e Leite (2015), a educação profissional pode ser definida como a busca da integração entre escola e trabalho, por meio de processo educacional planejado para a obtenção de conhecimentos, habilidades e comportamentos, visando aprendizagem que é aproveitada nos processos produtivos e que proporciona, por meio da prática, ações competentes na prática ocupacional. Centra-se em um currículo baseado nas competências, com metodologias voltadas para projetos ou resolução de problemas, não só rotineiros, mas também inusitados em seu campo de atuação. 
Nesse mesmo sentido, em vários países, há programas especiais de qualificação, como é o caso do México, que promoveu o programa de certificação de competências, visando fortalecer a empregabilidade das mulheres, jovens e afrodescendentes. Com esses imperativos, no Brasil, dentre os desafios para a formação profissional, expressas nas diretrizes nacionais para a qualificação do turismo, está o estímulo à qualificação de pessoas com deficiência, mulheres, idosos e grupos étnicos diversos, de modo a incentivar seu acesso ao mercado de trabalho e, ou, ascensão em suas carreiras (BRASIL, 2015).

No caso concreto do PMM, essa realidade também não é diferente, como apontam diversos estudos, como de Corcetti, Loreto e Pinto (2017), Alves (2015), Araújo (2015). Lagos (2014), Mendes e Silva (2015), Oliveira (2013) e Ribeiro (2013), ressaltando que a metodologia do programa de "Acesso, Permanência e Êxito", ao privilegiar as experiências e aprendizagem prévia das mulheres, tem oferecido cursos de curta duração e mais associados à domesticidade, com baixo impacto na elevação do nível de escolaridade e acesso ao emprego, embora tenham produzido aumento da autoestima e integração social.

Pressupõe-se, portanto, que o tipo de educação oferecido às mulheres tenha implicações em sua trajetória de vida, que perpassa pela biografia das pessoas, em função de suas experiências, projetos de vida e do espaço social vivenciado.

Nesse contexto, objetivou-se examinar a repercussão do PMM na trajetória de vida das mulheres inseridas tanto em atividades relacionadas ao turismo, quanto nos demais serviços. Especificamente, buscou-se identificar quais seriam as interfaces entre o PMM e 0 desenvolvimento das atividades turísticas, bem como examinar as percepções das mulheres sobre o programa e sobre suas implicações na trajetória de vida feminina, fazendo-se uso dos mapas da vida ${ }^{7}$.

\section{REVISÃO DE LITERATURA}

A revisão de literatura centrou-se em dois tópicos-chave do trabalho, que foram: Trajetórias de Vida e Mapas da Vida. 


\section{Trajetórias de Vida}

Bourdieu (1998) introduziu o conceito de trajetória de vida, articulando os significados de campo e habitus como posições ocupadas, sucessivamente, pelo agente num campo, sustentadas por sua história e ações, ou seja, por seu habitus. As trajetórias seriam, então, o resultado construído de um sistema de trocas e fatos pertinentes de uma biografia. Considerando que o campo está em constante mudança, a trajetória social é o movimento dentro de um campo definido estruturalmente, compreendendo A maneira singular de percorrer o espaço social, onde coexistem vários campos, constituídos de instituições e por agentes em constante relação e com regras próprias. É a inclinação da trajetória social que determina o sistema de disposições (habitus) que estrutura as práticas sociais.

Como ressalta Velho (1999), os projetos, longe de serem naturais e imutáveis, são construções dinâmicas relativas a determinadas escolhas, em determinado momento histórico de uma sociedade, estando em constante adaptação à realidade vivenciada. Representam planos e condutas orientados para atingir determinados fins, seguindo uma lógica sequência (ontem, hoje e amanhã), visando dar sentido às experiências vividas. Todavia, procura ver a escolha, não mais como categoria residual de explicação sociológica, mas sim, como elemento decisivo para a compreensão de processos globais de transformação da sociedade.

O referido autor acrescenta, ainda, que os projetos são elaborados e construídos em função das experiências pessoais, sociais e culturais; enfim, de vários códigos, que são interpretados conforme as vivências e interações. Os projetos são dinâmicos, e, como as pessoas, eles mudam, ou as pessoas mudam por suas escolhas; ou seja, seus projetos. Os projetos e a memória não só ordenam como dão significados à trajetória de vida, dentro do contexto de desenvolvimento; isto é, em função da estrutura social e processo social, desde o seu nível mais macro da organização até grupos menores, como escolas, família, comunidade e vizinhança.

Carborari (2007) discute a esse respeito ao afirmar que as possibilidades de escolha de cada indivíduo, a partir de suas circunstâncias, valores e interações cotidianas com seu meio, resultam em fluxo contínuo de ações projetadas, que singularizam o seu percurso ou trajetória de vida.

Desta forma, toda trajetória de vida é organizada baseada nos propósitos e objetivos específicos, marcada pelos fatos sociais e intersubjetivos das interações durante a vida. Guimarães (2004) comenta que as trajetórias dos indivíduos ganham consistência a partir do 
desenho de projetos com objetivos específicos. Sua viabilidade vai depender do jogo de interações com outros projetos individuais ou coletivos circunscritos no campo de possibilidades de cada situação; considerando que o comportamento se aprende, não somente pelo êxito, mas também pela experiência vivida por outros. Nesse sentido, faz-se necessário entender que os projetos estão relacionados ao mundo da intersubjetividade, podendo ser expressos por palavras, conceitos e categorias, que pressupõem a existência do "outro". Conforme a referida autora, o projeto é o instrumento básico de negociação da realidade com os outros atores, indivíduos ou coletivos.

Assim, o projeto de vida de cada ser humano é visto em função do seu processo de socialização e de outras circunstâncias, que se inserem no plano sócio histórico; isto é, no contexto mais amplo, que leva em conta o tempo, valores, crenças, vivências, interações, sociedade, cultura, dentre outros fatores, que dão significado à trajetória de vida.

Desse modo, principalmente na elaboração e execução de políticas públicas educacionais, com objetivos voltados para atender a público específico, se faz necessário compreender a existência de trajetórias de vidas diferenciadas, inclusive relativos à institucionalização de papéis sociais distintos entre homens e mulheres. Assim, conforme Levy, Gauthier e Widmer (2006), a trajetória de vida da mulher é variável e muito mais sensível, em comparação à trajetória de vida masculina, que é considerada mais homogênea e estável.

\section{Mapas da Vida}

Segundo Oliveira (2013), o Mapa da Vida é ferramenta no processo de construção do PMM, que objetiva criar oportunidade e ambiente para a troca de experiência de vida das mulheres, para que possam ser compartilhadas e, então, registradas, validadas e valorizadas.

De acordo com o Guia Metodológico do PMMo Mapa da Vida é um dos instrumentos metodológicos fundamentais do Sistema de Acesso, Permanência e Êxito. Trata-se de um momento emotivo e intenso, quando as alunas são convidadas a (re)ver momentos importantes do passado e presente, a (re)criar em suas mentes suas trajetórias de vida e a enumerar projetos de vida para o futuro. Possibilita que as mulheres materializem, de forma simples e significante, a família, o processo de escolarização, sua vida conjugal, a prole, as atividades laborais e os objetivos de vida (BRASIL 2012).

O objetivo da construção do Mapa da Vida, nos termos do referido Guia Metodológico, é fazer com que as mulheres reflitam sobre sua trajetória de vida, o que as estimula a organizar 
sua própria história, almejar coisas novas e, mais do que isso, resgatar memórias que, na maioria das vezes, se encontram apagadas. Além disso, com a construção do Mapa da Vida, as mulheres reafirmam que são capazes de fazer escolhas em suas vidas, resgatam a identidade, trocam experiências, têm seus saberes valorizados, possibilitando, ainda, que as mulheres se sintam como parte do processo. Com isso, podem ser percebidas suas necessidades, conhecimentos, realizações, sonhos, experiências e, também, lições de vida, dentre outros aspectos, considerados elementos essenciais no processo de formulação e implementação das políticas/programas sociais (BRASIL, 2012).

Enfim, o Mapa da Vida cumpre com o objetivo proposto de fortalecer, nas mulheres, a ideia e o sentimento de que elas são autoras da história de suas vidas; além de agir como articulador entre as participantes e os profissionais que irão orientá-las em diversos âmbitos dos cursos oferecidos pelo PMM. É por meio dele que se consegue traçar as metodologias que devem ser seguidas nos cursos oferecidos no programa; sendo, também, uma das formas de abordar as mulheres e de apresentar os temas para determinada situação, além de promover espaço de desabafo, mas também de promoção de sonhos e expectativas, com influências sobre o delineamento político.

De forma simples, esse instrumento faz com que a mulher se torne autora de sua vida, seja sonhadora, visualize o quanto mudou sua condição de vida e a estimula a pensar no melhor para si e sua família. Entende-se, então, que esse procedimento, simples e eficaz, representa um elemento importante para a identificação da trajetória de vida, além de criar oportunidades e ambiente para a troca de experiências de vida das mulheres, para que possam ser compartilhadas, devidamente registradas, validadas e valorizadas, contribuindo, inclusive, com a (re)composição da autoestima, da autonomia e do empoderamento feminino.

\section{PERCURSO METODOLÓGICO}

A metodologia de natureza qualitativa foi baseada em pesquisa bibliográfica e documental, além de entrevistas semiestruturadas com os executores do PMM, vinculado ao Instituto Federal de Educação, Ciência e Tecnologia do Sudeste de Minas Gerais (Campus Barbacena) e ao Instituto Federal de Educação de Educação, Ciência e Tecnologia do Espírito Santo (Campus Colatina, Vitória e Guarapari), com o intuito de obter uma visão geral da temática pesquisada e, ao mesmo tempo, um aprofundamento sobre a realidade dos fatos. 
No caso da pesquisa bibliográfica, foram considerados os artigos acadêmicos: Corcetti, Loreto e Pinto (2017), Rosa (2011), Silva (2106) e as dissertações de Alves (2015) e Oliveira (2013), dentre outras, disponíveis no portal Google Acadêmico, utilizando-se dos descritores: Programa Mulheres Mil.

No que concerne à pesquisa documental, foram tabulados e analisados 310 questionários socioeconômicos, 136 formulários intitulados "Avaliação do Programa ${ }^{8}$ e 310 Mapas da Vida ${ }^{9}$, realizados com as mulheres participantes do PMM, nos municípios de Barbacena (MG) e Barroso (MG), no período de realização dos cursos, das turmas oferecidas entre 2011 e 2014. Esses dados documentais foram tabulados e analisados, tanto pela estatística descritiva quanto pela análise de conteúdo e textual.

De acordo com os dados dos questionários socioeconômicos, a média de idade das mulheres estava entre 35 e 46 anos, mostrando ser público já adulto e com capacidade de construção de família e inserção no mercado de trabalho. No entanto, a maioria encontrava-se desempregada, sendo o marido o principal provedor da família, com renda média familiar que não ultrapassava a um salário mínimo. As mulheres, em geral, possuíam baixo nível de escolaridade (fundamental incompleto), tendo afirmado que os principais motivos para deixar de estudar estavam associados à gravidez precoce; perda ou falecimento dos pais; distância da escola em relação ao local onde viviam; além de limitadas condições financeiras/aprendizagem, tendo que trabalhar para ajudar em casa ou até cuidar dos irmãos/mãe. Em termos da composição familiar, o número médio de membros era de três, e mais de $80 \%$ das mulheres possuíam filhos, com média de 1 a 3 filhos.

Esse perfil feminino foi equivalente ao das mulheres do Espírito Santo (ES), uma vez que também se situavam na fase adulta (idade média entre 32 e 41 anos), a maioria casada, com média de 3 a 4 filhos. A situação ocupacional predominante era de desempregada, sendo a família sustentada pelo marido, com renda média mensal de menos de um salário mínimo da

8 Avaliação do programa - A coordenação do PMM, na cidade de Barbacena (MG) aplicou um questionário, intitulado "Avaliação do Programa", às concluintes dos cursos realizados no ano de 2012. Esse questionário teve o intuito de avaliar o trabalho desenvolvido naquela unidade de ensino, trazendo questões relacionadas às aulas, aos professores, aos gestores, visando compreender as implicações do PMM na vida daquelas mulheres e, ainda, diagnosticar futuras demandas para oferta de novos cursos.

9 O Mapa da vida é um instrumento que compõe a metodologia disposta no Guia Metodológico de Acesso, Permanência e Êxito. Geralmente, no momento de construção desse material, quando as mulheres narram sobre seu passado, presente e futuro, contam com a presença de uma assistente social, que, oportunamente, aproveita o momento para avaliar como é a vida dessas mulheres, se possuem algum problema/dificuldade e, a partir daí, fazer o acompanhamento com elas (ALVES, 2015). Essa narrativa foi complementada com as suas percepções sobre o PMM, objetivando identificar suas representações sobre os problemas e contribuições do programa no alcance da inclusão social, sendo atividades realizadas dentro do contexto de cada curso. Toda essa documentação foi examinada pela análise de conteúdo e textual. 
época da pesquisa (2014/2015), aproximadamente $\mathrm{R} \$ 620,00$. Possuíam também baixo nível de escolaridade, equivalente ao ensino fundamental incompleto. Esse documento sobre a "Avaliação do Programa" continha 277 entrevistas, que foram tabuladas e examinadas, considerando apenas as egressas do PMM de Vitória, Guarapari e Colatina, no estado do Espírito Santo, que foram inseridas nas atividades relacionadas ao turismo, que foram: a Associação das "Paneleiras de Goiabeiras" e "Desfiadeiras de Siri" das Ilhas das Caieiras, do município de Vitória (ES); mulheres qualificadas para a função de camareira, secretária e garçonete, da cidade turística de Guarapari (ES); bem como camareiras, que foi curso indicado pela prefeitura da cidade de Colatina (ES), dada a instalação de um hotel, na localidade. Muitos dos trechos das entrevistas utilizados na pesquisa foram reproduzidos na íntegra.

Visando a complementação das informações, foi realizada também, uma pesquisa primária, com aplicação de entrevista, em seus locais de trabalho, com seis gestores do PMM, três em cada estado, servidores dos referidos Institutos Federais, que coordenaram o programa nas localidades anteriormente citadas, com as seguintes indagações: "Como foi o acesso das mulheres ao programa"? "Como foram definidos os tipos e conteúdo dos cursos oferecidos pelo PMM? Teve cursos voltados para o turismo? Quais? Por que foram inseridos?”.

A análise de conteúdo, referentes às informações qualitativas do Mapa da Vida, permitiu analisar os três momentos (passado, presente e futuro), que representam a trajetória de vida das mulheres, se pautando na metodologia proposta por Bardin (2011), complementada com o uso do software de análise lexical IRaMuTeQ (Interface de R pourles Analyses Multidimensionnelles de Texteset de Questionnaires), desenvolvido por Pierre Ratinaud, que, por meio de seu ambiente R, permite a Análise de Textos (Corpus Textual) e de Tabelas de Caracteres(Matriz de Dados), como exposto por Camargo e Justo (2013).

Para esses autores, a análise lexical é um tipo específico de análise de dados, na qual se trabalha o material verbal transcrito; ou seja, textos originalmente escritos, entrevistas, documentos, etc., permitindo realizar diversas análises, como: Análises lexicográficas clássicas - que identificam a quantidade de palavras, frequência, média, pesquisa o vocabulário e reduz as palavras com base em suas raízes (formas reduzidas), identificando as formas ativas e suplementares; Análise de especificidades e Análise Fatorial Confirmatória, que associa os textos com variáveis; ou seja, possibilita a análise da produção textual em função das variáveis de caracterização e também a apresentação em plano fatorial; Análise de Similitude, que possibilita identificar as ocorrências entre as palavras e seu resultado, trazendo indicações da 
conexidade entre as palavras e auxiliando na identificação da estrutura da representação; além da Classificação Hierárquica Descendente e da Nuvem de palavras.

No estudo em questão foi feito uso de: a) Nuvem de palavras sobre o passado, presente e futuro, a qual agrupou as palavras evocadas pelas mulheres, organizando-as graficamente em função da sua frequência; b) Análise de Similitude, que procurou examinar a ligação entre as palavras de todo o corpus textual, buscando-se inferir sobre temas de relativa importância e sobre a estrutura de construção do texto, como afirma Lins (2017); c) Classificação Hierárquica Descendente (CHD), conforme método descrito por Reinert e por matrizes de distância, citados por Camargo e Justo (2013).

\section{RESULTADOS E DISCUSSÃo}

\section{Interfaces do PMM com o Turismo}

Para a análise das percepções sobre as interfaces do PMM com o turismo foram examinados os dados obtidos por meio de entrevistas como os coordenadores dos programas, nas cinco localidades pesquisadas. Na opinião dos gestores, a seleção dos cursos, em geral, não tinha como prioridade o desenvolvimento do turismo local, com exceção do município de Vitória, no estado do Espírito Santo, onde as mulheres já se encontravam organizadas em associação, especificamente, a Associação das Paneleiras de Goiabeiras e das Desfiadeiras de Siri.

Nesse sentido, os cursos de capacitação oferecidos privilegiavam o conhecimento e as experiências prévias femininas, bem como suas demandas, em termos de seus projetos de vida. Assim, se as mulheres já trabalhavam com artesanato, indicavam esse curso, visando à melhoria de seus produtos e maior capacidade de venda. Dessa forma, reconhece-se a possibilidade de interfaces, pelo tipo de curso realizado, como é o caso da informática, camareira, auxiliar de cozinha, administração e artesanato, em termos da prestação de serviços em hotéis, restaurantes, dentre outros equipamentos de turismo; além da possibilidade do trabalho autônomo, como artesãs.

Especificamente, quanto aos cursos voltados para a atividade turística, foi relatado pelos gestores do programa, oferecido pelo Campus Barbacena do Instituto Federal do Sudeste de Minas Gerais, nas localidades de Barbacena (2) e Barroso (1), que: 
Não o nosso recepcionista é mais para escritório, para consultório, não é pra os meios de hospedagem. Não, por exemplo, não a gente teve uma turma que saiu do nosso Mulheres Mil e ela fez recepcionista de eventos no Pronatec. A turma foi exclusiva para egressas do Mulheres Mil no Pronatec, entendeu? Mas, essa recepcionista nossa, é, porque está engessada mesmo na escolaridade. Tinha que ter um curso para quem tem fundamental II incompleto e tem aquelas que não gostam de cozinha. Então foi o que a gente tinha de opção, não é? E não é voltado pra, pra parte de turismo não. (E1, Barbacena, MG)

Nós tentamos deixar fixa uma barraquinha para elas no centro, a gente não conseguiu por causa, que barra na prefeitura. Quando tinha eventos igual tipo a FECIB, FEICOB essa coisas aí a gente montava a barraquinha do Mulheres Mil, entendeu? Um stand mesmo para a divulgação do curso, aí a gente acabava vendendo alguma coisa, que revertia em material mesmo, pra elas não tinha retorno. A gente fez até em Recife, a gente foi no Fórum Mundial em Recife. Nossa, elas ficaram deslumbradas, né? E, aí a gente fazia muitas tardes aqui fora de aula, sentava todo mundo aqui produzindo pra mandar pra fora, sabe? (E1, Barbacena, MG)

Não virou um empreendedorismo. Porque elas não conseguem essa associação, tinha que ter uma associação se não o quê que é isso que elas vendem, né? (E2, Barbacena, MG)

[...] Aí, dentro do curso é que elas aprenderam coisas de artesanato, que poderia focar no turismo. [...] Teve artesanato, porque o curso, foi assim, teve essas partes das aulas, [...] a gente teve esses cursos de artesanato, que foi ensinado a elas a bordar, a ensinar a fazer objetos, num caso elas fizeram, aprenderam a fazer umas flores assim bonitas, de lata assim, pintada, muito bonita. Então, teve esse, três fases do curso, tudo intercalando no mesmo projeto. (E3, Barroso, MG).

Os depoimentos dos gestores evidenciam a necessidade de maior nível de escolaridade das mulheres, além de empreendedorismo e formação de associação, para avanço na consolidação das atividades turísticas. Essa mesma questão foi relatada pelos gestores do PMM, no Estado do Espírito Santo, com respeito aos cursos voltados para atividade turística, pois, mesmo que a equipe técnica tenha despendido esforços para que as atividades de artesanato fossem transformadas em empreendimento, poucas ações foram implementadas nesse sentido. Acreditam que esse empreendimento depende de cada uma das egressas, da iniciativa individual e do ganho de conhecimentos e, como a maioria, além de possuir baixo nível de escolaridade (fundamental incompleto), era responsável pelo cuidado da casa e dos filhos, sendo dependentes do marido, restava-Ihes pouco tempo para se dedicar integralmente à atividade turística.

Esse ponto é discutido por Souza e Silva (2010), ao pontuarem que a educação e o turismo apresentam pontos de convergência, uma vez que seu desenvolvimento de forma mais sustentada depende de estratégias educativas, que contemplem a construção do conhecimento criativo, transformador, crítico e participativo. Ou seja, a instrumentalização para o turismo não pode ser feita por meio de programas imediatistas (como foi o caso do PMM, com os cursos de 
Formação Integrada Continuada-FIC) e com visão apenas mercadológica, sem sensibilização consciente e percepção crítica dos alunos sobre a atividade turística.

$\mathrm{Na}$ percepção das autoras, isto envolveria maior carga horária, com aulas interativas; habilidades e comportamentos adequados para o relacionamento interpessoal, com criação de parcerias, que propiciassem visitas de campo, participação em eventos, dentre outros; ou seja, deveria ocorrer diálogo entre a teoria e a prática, adequada para aprendizagem significativa e focada na realidade.

As egressas do PMM de Barbacena (MG) participaram da Feira Científica de Barbacena (FECIB), Feira do Comércio de Barbacena (FEICOB) e do Fórum Mundial de Educação Profissional e Tecnológica (FMEPT), eventos esporádicos, como um marketing do programa, sem a finalidade de trabalhar o tema turismo, de maneira consistente e eficaz. A baixa escolaridade feminina também refletiu na ausência do empreendedorismo, na criação de associações, que pudessem alavancar, por exemplo, o artesanato.

Além disso, não houve o apoio da prefeitura para o fornecimento dos equipamentos turísticos, conjugado com a ausência de políticas para o turismo, com ações intersetorizadas e com o estabelecimento de regras e diretrizes a serem cumpridas a longo e médio prazo, que deveriam abranger os aspectos culturais, ambientais e sociais. Ou seja, foi observado fragilidade na formação de parcerias, principalmente, com as prefeituras, para impulsionar o PMM, como também o desenvolvimento local, por meio da ampliação e consolidação do setor de turismo.

As percepções positivas sobre o Curso Gestão e Relacionamento com o Cliente demonstram a importância das vivências e experiências já possuídas pelas artesãs, bem como por estarem organizadas em associação. Nesse caso, já tinham consciência de quais conhecimentos seriam mais necessários, seja na própria gestão do negócio (relação de custos e receitas, aprendizagem na área de computação), seja no relacionamento com o cliente (extroversão e comunicação). Assim, poderiam alcançar vantagem competitiva para o turismo, quando o foco é o consumidor ou o cliente, buscando-se melhorias no relacionamento e na qualidade dos serviços/produtos ofertados.

Nesse sentido, como apontam Coelho, Ribeiro e Fontes Filho (2018), a empresa, dentro da economia da experiência, não oferta apenas produtos, mas passa a lidar com sensações e heranças culturais, visando o atendimento das necessidades dos clientes e superação de suas expectativas. 


\section{Percepções das egressas sobre o PMM}

Os resultados apurados na análise do questionário intitulado "Avaliação do Programa", realizado pela coordenação do PMM, na cidade de Barbacena (MG), bem como das entrevistas com as egressas do PMM, no Espírito Santo, evidenciaram que, na percepção das mulheres, o programa foi visto como um marco em suas trajetórias de vida.

Especificamente, com respeito aos professores, foi unânime a opinião das mulheres sobre o comprometimento de todos, como relatado por uma das respondentes:

"Gostei de todos, pois todos me ajudaram muito e me ensinaram coisas não só dentro do curso, mas, para o longo da vida" (Egressa 1, Barbacena, MG).

Em termos dos cursos oferecidos, as preferências declaradas pelas egressas do PMM, foram: Saúde da Mulher, Psicologia, Autoestima e Etiqueta à Mesa, seguidos por Direitos da Mulher, Informática e artesanato, dentre outros. As egressas, além de manifestarem satisfação com as aulas e professores, consideraram que o programa proporcionou maior autoestima, reconhecimento do trabalho realizado e aumento da consciência sobre a importância da saúde da mulher e de seus direitos, como expresso nas seguintes falas:

"Foi muito proveitoso, porque através delas tivemos as chances de esclarecer muita dúvida que, em lugar algum, não teríamos e, também, pela timidez nunca teríamos a coragem de perguntar. Espero que continue."(Egressa 2, Barbacena, MG );

"Não tenho nada a reclamar, todas as etapas que passei foi proveitosas, e muito interessantes, se pudesse fazer de novo eu faria, pois mudou muito meu dia a dia."(Egressa 3, Barbacena, MG).

"Para mim houve uma melhoria na saúde, tive depressão e o curso me deu um "up" e estou conseguindo melhorar a relação com a minha família, mudei meu estilo de vida." (Egressa 11, Vitória, ES).

Entretanto, apesar das vantagens oferecidas pelo PMM, a maioria das mulheres não continuou os estudos após o Programa, alegando não terem com quem deixar os filhos e netos, bem como a falta de recursos, como reportado:

"Gostaria de fazer curso superior, porém não tenho como pagar a mensalidade." (Egressa4, Barbacena, MG).

"Eu estava fazendo o técnico, porém por estar trabalhando em dois empregos, eu não tive como continuar pela falta de tempo, mas gostaria de poder fazer" (Egressa 8, Colatina, $E S)$. 
$\mathrm{Na}$ opinião das entrevistadas, as aulas foram ótimas; embora o tempo fosse curto; declarando que muitas se encontram há anos sem estudar e necessitam de maior base, com mais aulas práticas. Ressaltaram ter maior dificuldade com a matemática, cujo ensinamento poderia aumentar e melhorar. Para tanto, na opinião das mulheres, essas aulas de melhoria do nível de escolaridade deveriam ter começado no início do programa, com maior carga horária, como reportado:

\footnotetext{
"Todos os professores ou auxiliares fizeram o que puderam, mas o tempo da prática escolar foi pouco, a chance é pouca." (Egressa 5, Barbacena, MG).

"Ter mais aulas práticas, pois o curso foi bom, mas precisa ter aulas práticas." (Egressa 6, Barbacena, MG).
}

Essa opinião foi também relatada pelas egressas do Espírito Santo, ao afirmarem que gostariam que os cursos tivessem carga horária maior, principalmente de aulas práticas, alegando não se sentirem totalmente preparadas para realizarem seus serviços com a qualidade exigida pelo mercado. Outra solicitação foi com relação ao acesso ao microcrédito para comprarem equipamentos, matérias-primas e instrumentos de trabalho para exercerem as atividades que aprenderam no programa.

Nesse caso do próprio empreendimento, quando perguntado às egressas se sentiam preparadas para montar um negócio, a respostas das mulheres de Vitória (ES) foram: “Eu não, para montar tem que ter mais capacitação, mais conhecimento. Conhecimento de leis, de como montar um negócio”; enquanto outra comentou: “... quanto que você gasta, quanto você ganha, do tempo que você começa até o tempo que você ganhar aquele dinheiro, é... cobrir o dinheiro que foi gasto". Ou seja, o programa também não foi capaz de despertar o desejo de empreender e, apesar de as egressas terem sido informadas sobre o microempreendedor individual, a maioria que trabalhava informalmente não se interessou pelo incentivo.

Por outro lado, também enfrentaram dificuldades para inserção no mercado de trabalho, como pontuado por algumas egressas:

"Acho que a parte prática, como no curso de cuidador, deveria ir a mais lugares não só em asilos, ir em outras áreas que houvessem idosos para vermos a rotina da profissão em vários ambientes" (Egressa 9, Colatina, ES).

"O que eu não gostei foi eu ter estudado, ter feito o possível e não ter respostas." (Egressa7, Barbacena, MG). 
Esse resultado está coerente com o estudo de Silva (2016), ao afirmar que o PMM não consegue romper com problemas históricos associados à questão de gênero, embora avance com respeito à estratégia metodológica, que apresenta condições de sensibilizar as mulheres, em termos da possibilidade de mudança em suas trajetórias de vida.

Assim, as sugestões para maior alcance do programa estão centradas no aumento das aulas práticas e, portanto, maior tempo do curso, com maiores chances para elevação no nível de escolaridade, melhor capacitação profissional e condições de inserção no mercado de trabalho, seja em atividades turísticas ou qualquer outro serviço, de forma que ocorra alterações nas trajetórias de vida.

\section{Implicações do PMM na trajetória de vida das mulheres}

A trajetória de vida das mulheres foi analisada pelos Mapas da Vida, considerando suas narrativas sobre a vida passada, situação presente e expectativas futuras.

Em relação ao Mapa da Vida, examinado pela análise de conteúdo, constatou-se que pequena parcela das mulheres declarou ter tido infância feliz, tranquila e cheia de sonhos, com os pais e irmãos unidos. A maioria delas afirmou ter uma vida sofrida, com muitas carências (alimentares, habitacionais, entre outras), com pais alcoólatras, vivendo situações de agressão, separação dos pais, gravidez precoce, além do abandono dos estudos. Ou seja, o passado foi caracterizado por ambientes de muita precariedade, que levam ao trabalho infantil (principalmente na roça ou em casa de família) e abandono do estudo, com situações de gravidez precoce, alcoolismo e violência, famílias quebradas, dentre outras mazelas.

Considerando os discursos das mulheres do PMM, examinados pelo IRaMuTeQ, verificouse, pela nuvem de palavras, conforme indicador de frequência, que as palavras mais evocadas foram: filho, pai, vida, irmão, família e trabalhar (Fig. 1). 
Figura 1 - Nuvem de palavras indicativas do Passado das Mulheres do PMM

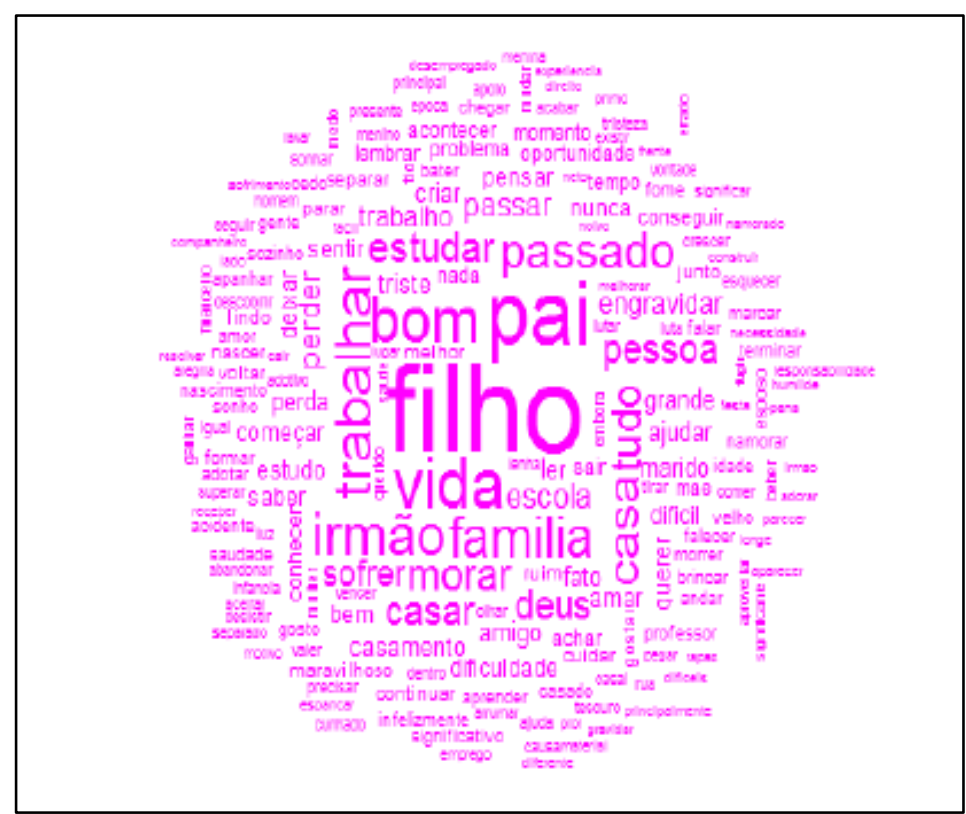

Fonte: Dados da Pesquisa Documental (2014), analisados com o auxílio do software IRaMuTeQ.

Dessa forma, foi possível observar, conforme segmentos de textos gerados pelo programa estatístico, que as mulheres em seus discursos sobre o passado, fazem muita menção à família, nas figuras do pai, filho e irmão, comentando ter tido vida sofrida, de trabalho e muitas carências, como abaixo especificado:

"Na minha adolescência tive que trabalhar muito cedo cuidando dos meus irmãos e sobrinhos, trabalhando na roça para poder ajudar meus pais, passamos muitas dificuldades, íamos para a escola às vezes até sem o café da manhã, porque não tínhamos o que comer, minha vida não foi fácil"

Com respeito à situação presente vivida pelas mulheres, foi relatado, pela maioria, como sendo bem melhor, comparativamente ao passado, pela felicidade de poder estar com a família, principalmente com os filhos, além de possuir bens que anteriormente não tinham acesso. Ou seja, conforme Figura2, a mulher sente-se mais feliz, por ter sua família e casa, estar junto de seus filhos e marido, trabalhar, e com Deus na sua vida. Além de estarem participando do programa ("curso"), que é visto como "uma maravilha" em suas vidas, oportunidade para que possam elevar o nível de escolaridade, ter uma profissão e trabalho estável, bem como proporcionar futuro melhor para a sua família, em especial para os filhos. 
Figura 2- Nuvem de palavras indicativas do Presente das Mulheres do PMM

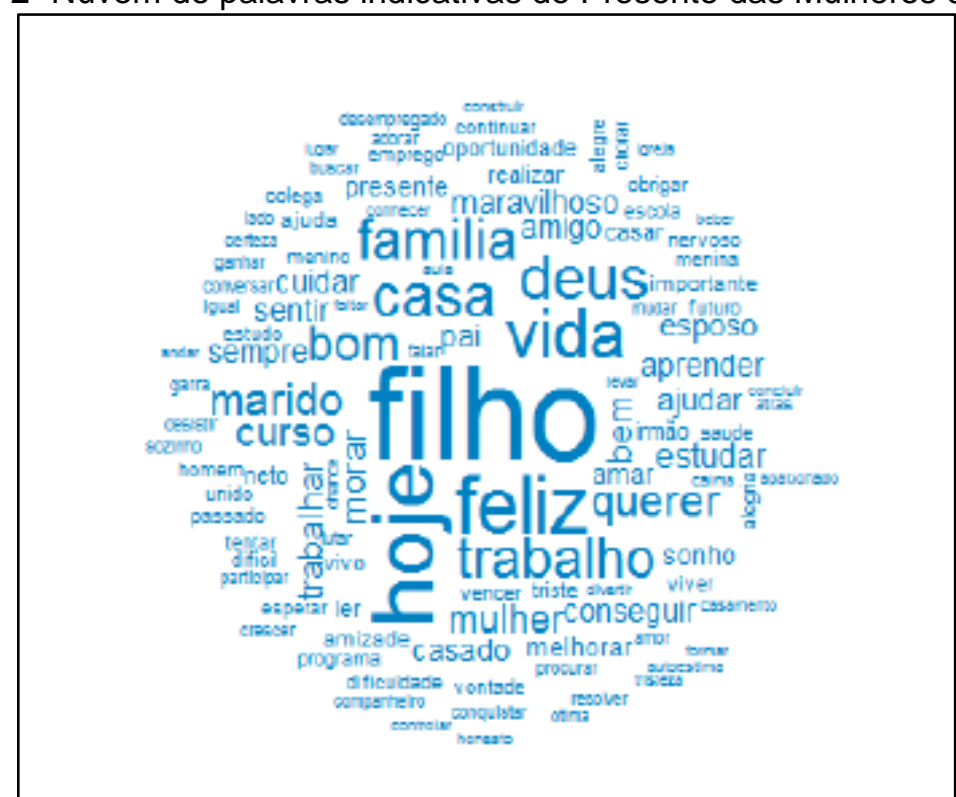

Fonte: Dados da Pesquisa Documental (2014), analisados com o auxílio do software IRaMuTeQ.

No trecho abaixo, extraído do IRaMuTeQ, pode-se observar QUE as mulheres se sentem mais felizes, com a vida que levam hoje, no presente. Novamente voltam a falar da importância dos filhos, da família e de Deus em suas vidas:

"Sou uma mulher de 50 anos, casada, tenho dois filhos e um neto maravilhoso, que eu amo de paixão. Eu me sinto uma pessoa feliz e quero continuar assim e que Deus nos abençoe e Santíssimo Sacramento nos proteja"

As mulheres tinham muitos sonhos com respeito ao futuro; esperavam e queriam ter uma vida melhor. Essas expectativas envolviam ter mais estudos e uma profissão melhor; lugar no espaço laboral, com os cursos realizados; conseguir uma casa própria; e, principalmente, uma vida melhor para os filhos, por meio da educação e do trabalho, conforme palavras evocadas e apresentadas na Figura 3. 
Figura 3- Nuvem de palavras evocadas pelas mulheres do PMM sobre o Futuro

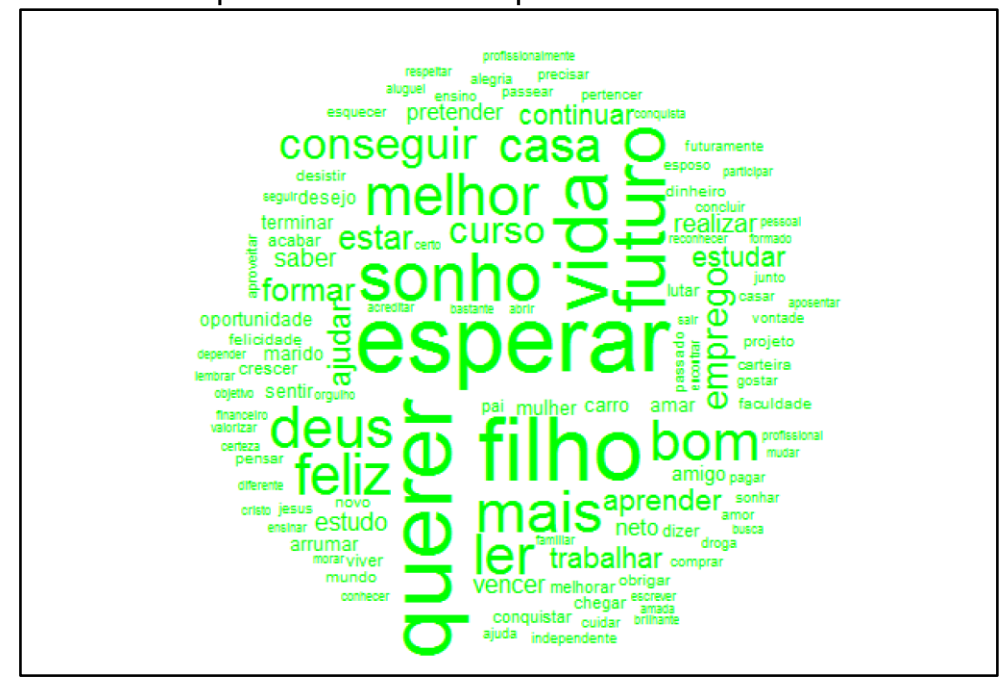

Fonte: Dados da Pesquisa Documental (2014), analisados com o auxílio do software IRaMuTeQ.

As palavras evocadas pelas mulheres foram materializadas em seus discursos, agrupadas em segmentos de textos, como exposto a seguir:

\footnotetext{
"Meu sonho não é riqueza, é sossego paz, é só o que eu quero para toda minha família, espero poder ajudar minhas filhas a estudar, para arrumar um bom emprego e ser feliz, espero que toda minha família continue unida e sejamos muito felizes"
}

Os resultados encontrados estão coerentes com a pesquisa de Alves (2015), ao relatar que, na construção do Mapa da Vida, as alunas do Instituto Federal de Goiás se emocionaram muito ao falar da infância, de como viveram, de como estavam naquela fase da vida e de como alcançaram o que tinham até então. Na maioria dos relatos, as mulheres demonstraram o desejo de mudar de vida; ou seja, almejavam um trabalho que melhorasse sua renda ou, até mesmo, terem seu próprio negócio, a partir do que iriam aprender no programa. Assim, ao construírem o Mapa da Vida, as participantes do PMM, conseguem ir delineando seu projeto de conhecimento à medida que narram suas histórias que são condicionadas por fatores culturais, políticos, sociais, religiosos, econômicos e ambientais.

Em seguida, a partir da teoria dos grafos, foi realizada a Análise de Similitudes, com o auxílio do software IRaMuTeQ, visando identificar a conexidade entre as palavras, explicativas da estrutura do conteúdo, representativo da trajetória de vida das mulheres. Assim, considerando os três tempos (passado, presente e futuro), as três palavras, que mais se destacaram nos discursos foram: "Filho", "Muito" e "Não", conforme Fig. 4. 
Figura 4 - Grafo de similitude representativa da Trajetória de Vida das mulheres do PMM.

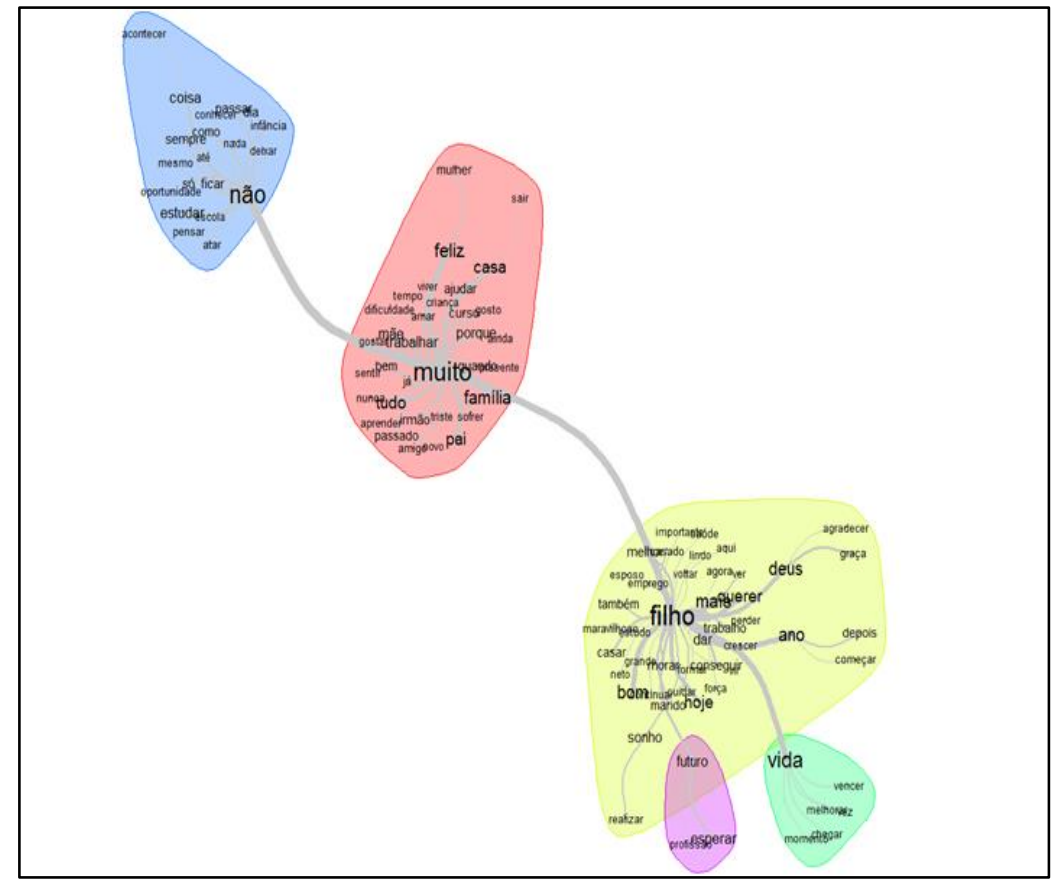

Fonte: Dados da Pesquisa Documental (2014), analisados com o auxílio do software IRaMuTeQ.

A palavra "Filho" perpassa por todo curso de vida da mulher, seja no presente, passado e futuro. Ela se ramifica com outras de expressão significativa, que são: "Vida", "Futuro" e "Deus", indicando que ela deseja uma vida e um futuro melhor para os filhos e que agradece a Deus por tê-los em sua vida.

Essa importância dada aos filhos reafirma e reforça o papel cuidador e reprodutor da mulher no interior de suas tramas discursivas, determinando, assim, que a formação de subjetividades femininas esteja associada às premissas de cuidado e proteção da família, especialmente dos filhos (CORSETTI; LORETO; PINTO, 2017).

A palavra "Muito" é a expressão significativa da felicidade, pois, no presente, se sente muito feliz por sua família e por sua casa, comparativamente ao passado, que pode ser representado pela palavra "Não", expressando suas percepções negativas, em termos de infância, estudo e oportunidades limitadas.

No estudo em questão, também foi realizada a Classificação Hierárquica Descendente, apresentada na Figura 5, que analisou o conjunto de textos, referente às falas das mulheres, apresentadas no Mapa da Vida, que constituiu o corpus, que foi submetido à análise, desmembrando-se em 656 seguimentos de textos, com aproveitamento de 78,38\% do texto, com 30.563 mil ocorrências (palavras, formas ou vocábulos), sendo 2.037 mil palavras distintas, 1.850 formas ativas, 179 formas suplementares. 
Do corpus processado pelo IraMuTeQ, foram categorizadas cinco classes temáticas, apresentadas na Figura 5, que traça um dendograma, com as classes divididas em cores, contendo a porcentagem de vocábulos em cada uma delas, bem como as palavras que compõe cada classe.

É possível observar que as cinco classes foram inicialmente divididas em duas ramificações $(A$ e $B$ ) do corpus total em análise. A ramificação $A$ compreendeu dois subcorpus, que incluem as Classe 2 e 1, que representam, respectivamente, $21,8 \%$ relacionadas à "A Infância da Mulher" e 18,1\% relacionados ao "Do passado ao presente: A Mulher na sua Vida Adulta", que mostra a integração dessas fases da vida.

Por outro lado, a ramificação B contempla três subcorpora, que são as Classes 4, 3 e 5, e esta última encontra-se separada das duas anteriores. Essas classes foram assim denominadas: "Experiências com o PMM", que contém os discursos da Classe 4 (15,7\%); "Vivências do Presente", que contempla a Classe 3 (18,3\%), o que demonstra a realidade presente, com destaque para a importância do Programa, na sua trajetória de vida; e, em seguida, tem-se, separadamente, a Classe 5, denominada "Expectativas do Futuro", que corresponde a $26,1 \%$ dos vocábulos analisados.

Figura 5 - Dendograma representativo das Classes Temáticas associadas à Trajetória de Vida das mulheres do PMM, em percentual

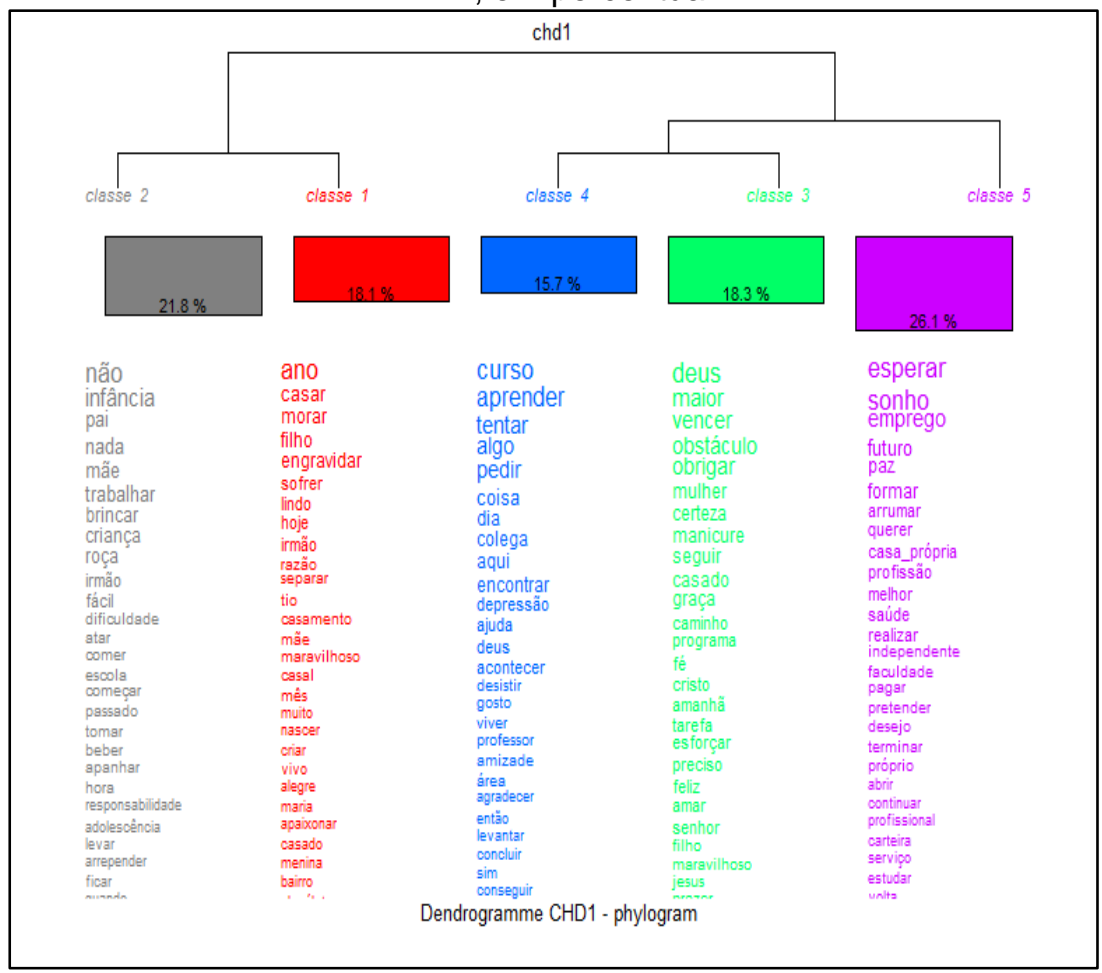

Fonte: Dados da Pesquisa Documental (2014), analisados com o auxílio do software IRaMuTeQ. 
Examinando cada classe separadamente, tem-se a classe 1, denominada "Do passado ao presente: A mulher na sua Vida Adulta", que foi constituída por 119 segmentos de textos, representando $18,1 \%$ do total do corpus, sendo formada por palavras, como: ano, casar, morar, filho, engravidar, sofrer, hoje, dentre outras. Nessa classe, a mulher faz um relato da sua vida atual, mas remetendo-se ao passado, mostrando suas conexões.

A seguir estão listados alguns segmentos de textos, que justificam a denominação desta classe:

"Meu passado não foi muito bom vim de família humilde, mas de trabalhadores, tenho hoje 57 anos, me casei muito cedo aos 16 anos, no ano de 1975"

"Hoje sou uma pessoa feliz, me casei de novo com uma ótima pessoa, me ajudou a ser uma pessoa mais aberta e comunicativa. Este ano foi o ano da minha libertação hoje sou outra pessoa"

"Aos 16 anos fui morar com um cara, que hoje é meu marido e não tive um relacionamento muito bom e, em pouco tempo, engravidei e tive meu filho aos 17 anos. Esse cara me fez sofrer muito, pois ele ainda era um moleque

"Me casei com 19 anos. não tive muita sorte, me separei com 11 anos depois, com 4 filhos, acabei criando sozinha, mas hoje tudo é diferente"

A classe 2, intitulada "A Infância da Mulher", conteve 143 segmentos de textos, correspondendo a $21,8 \%$ do total do corpus, sendo composta pelas seguintes palavras: não, infância, pai, nada, mãe, trabalhar, brincar, roça, irmão, dificuldade. A seguir, são citados alguns segmentos de textos, que constituíram esta classe:

"Minha infância foi curta, embora não tivesse brinquedos comprados em lojas, brincava com as bonecas de pano que minha mãe nos ensinava fazer, meus irmãos com as bolas feitas de meia; éramos crianças limitadas, Minha mãe, como a maioria das mães, trabalhava, sempre atenciosa, meu pai era muito rígido, tudo fazia ficar irritado"

"Bom, meu passado é um pouco frustrante, não tive infância, porque tive que trabalhar para ajudar meus pais, buscar lenha, água e muito mais, ainda arrumar tempo para estudar. Aos 16 anos fui mãe, não tive uma experiência muito boa, mas sou feliz pelo meu filho que Deus me deu"

"Estudei até a $5^{a}$ série, ai fiquei grávida e parei com tudo; não tinha terminado os estudos e seguindo o caminho errado, que achei mais fácil. Meu passado não foi muito fácil passei muitas dificuldades, porque a minha mãe criou eu e meus irmãos sozinha".

"Meu passado era muito ruim, eu trabalhava muito na roça, nunca tive infância, nunca ganhei uma boneca para brincar. Meus brinquedos eram meus irmãos porque tinha que ajudar minha mãe criar, porque éramos muitos"

A classe 3, denominada Vivências do Presente", formada por 103 seguimentos de textos, contabilizou $18,3 \%$ do corpus, sendo composta por palavras, tais como: Deus, maior, vencer, 
obstáculo, obrigar, mulher, certeza, manicure, que evidenciam a vida da mulher, sendo listados seguimentos de textos, que exemplificam o que pensam da sua realidade atual, fazendo menção ao curso realizado e a participação no PMM:

"Hoje, apesar de tudo, estou realizando meus sonhos que é estudar para fazer algo que gosto. Tenho meus filhos, que é uma benção de Deus, apesar de tudo que já passei, hoje sou uma mulher realizada, eles me dão mais força para que eu não desista"-

"Espero também ter um emprego na área em que curso, padaria, para que eu possa todos os dias aprender um pouco mais, espero ainda um dia poder encontrar todas as minhas colegas de curso para ver todo o indo bem e desejo que todas tenham um futuro pleno e cheio de felicidade".

"O futuro, eu espero que seja melhor que hoje, me vejo trabalhando na área que eu gosto, fazendo o que eu gosto, porque esse tempo que eu passei, fazendo o curso de doces, aprendi muita coisa e isso aumentou ainda mais minha vontade de trabalhar em casa e fora".

"Sou uma mulher muito feliz, porque ter duas filhas e ter conhecido várias mulheres, que fizemos uma corrente de amizade muito bonita, agradeço a Deus todos os dias por fazer este curso e ter conhecido cada uma das minhas colegas"

A classe 4, conceituada de "Experiências com o PMM", com 120 seguimentos de textos, corresponde a $15,7 \%$ do total do corpus, sendo composta por palavras, tais como: curso, aprende, tentar, algo, pedir, coisa, dia, colega, etc. A seguir, são listados seguimento de texto que exemplificam o que pensam as mulheres sobre o curso:

"Com amor a Deus, vamos combatendo uma a uma e agora, com o Programa Mulheres Mil, tenho certeza que consigo mais ainda, vou vencer as dificuldades e os obstáculos que a vida nos reserva e tenho certeza que sou e serei muito feliz"

"Tenho um esposo maravilhoso na minha vida, minha mãe que é uma benção de Deus, ela é tudo pra mim, estou feliz por estar no Mulheres Mil, tenho certeza que minha vida vai mudar, sou dona de casa

"Participar das tarefas dos meus filhos, ler jornais e fui aperfeiçoando, agora, com o projeto, eu espero conseguir o certificado do ensino fundamental, eu estudei há 42 anos, nunca mais pisei na escola, tudo que sei dou graças a Deus"

"Estou sentindo no momento, uma enorme felicidade, pois Deus colocou no meu caminho o Programa Mulheres Mil e, junto com ele, o meu sonho passou a ser real; ou seja, estou estudando e me sentindo novamente feliz e realizada"

Por fim, a classe 5, denominada "Expectativas do Futuro", conteve 171 seguimentos de textos expressando $26,1 \%$ do corpus. Foi composta pelas seguintes palavras: esperar, sonho, emprego, futuro, paz, formar, arrumar, querer casa própria, profissão, melhor, dentre outras. A seguir são listados alguns segmentos de textos, que constituíram essa classe: 
"Eu sonho em formar em alguma coisa e ser alguém na vida e uma profissão, aproveitar a oportunidade que meus pais nem tiveram, espero saindo daqui arrumar um bom emprego ter minha própria casa e terminando este curso quero fazer outro, que minha familia se espelhe em mim"

"Meu sonho é viver sempre em união, com quem eu amo, ter saúde, paz e ser feliz, espero que eu consiga um emprego melhor, para que eu consiga adquirir uma casa boa, um carro etc. Espero também ter muita saúde"

"Para o meu futuro, espero conseguir concluir meus estudos e consegui chegar onde sempre quis chegar. Sonho em comprar minha casa própria, conseguir um bom emprego, depois que concluir meus estudos e, sem esquecer, que quero viajar muito"

"Eu espero do futuro poder dar uma vida melhor pros meus filhos, conseguir realizar o meu sonho, que é terminar os estudos e ter uma profissão, conquistar meu espaço no mundo com dignidade"

Em função dos resultados da Classificação Hierárquica Descendente, pode-se inferir que a trajetória de vida não é linear, existindo integração entre o passado e o presente, que foi marcado por um evento importante na vida das mulheres, no caso, o PMM, que levou a mudanças, em função do espaço e "tempo vivido". Assim, o PMM representou uma bifurcação na trajetória de vida das mulheres, que, segundo Reis (2010), são pontos ou experiências que marcam a vida das pessoas, que devem ser ultrapassadas, para que estas possam alcançar certas condições no seu desenvolvimento.

Na visão da autora, estudos na área de psicologia cultural têm enfatizado a construção de sentidos e significados que as pessoas atribuem às suas experiências de vida, considerando as condições do espaço ou contexto de desenvolvimento e o tempo (do que foi e não pode ser alterado e do que virá). Considera também que, no enfrentamento das circunstâncias impostas pela vida, positivas ou não, o indivíduo cria significados, pois enfrenta diferentes opções de escolha que exigem posicionamentos ou tomada de decisão, com influência nas perspectivas futuras, como foi o caso do PMM.

\section{CONCLUSÃO}

Os resultados permitem concluir que o alcance do PMM foi limitado, pois, apesar de haver contribuído para uma realidade presente "mais feliz", pela elevação da autoestima, motivação e integração social, como apresentado no mapa da vida das mulheres, não proporcionou o aumento do nível educacional feminino e a inclusão profissional, pois o conteúdo e a carga horária dos cursos foram pontuais e limitados, sendo necessárias mais aulas interativas, maior 
diálogo entre a teoria e a prática, para a ocorrência de aprendizagem significativa e focada na realidade, que proporcione inserção no mercado laboral e autonomia econômica.

Em geral, os cursos oferecidos pelo PMM foram de curta duração, privilegiando o conhecimento e as experiências prévias das mulheres, além de suas demandas; possuindo, portanto, limitada interlocução com o desenvolvimento de setores locais, como é caso do turismo, com exceção daquelas atividades já desempenhadas de forma associativa pelo segmento feminino, como foi o caso da Associação das Paneleiras de Goiabeiras e das Desfiadeiras de Siri, que demandaram um curso sobre Gestão e Relacionamento com o Cliente, para que pudessem ter conhecimentos sobre o processo de gestão do negócio, oferta de um produto ou serviço com mais qualidade, por meio de melhor relacionamento com o público consumidor. Ou seja, ocorreram melhorias pontuais, naqueles casos onde já existia certa organização das mulheres, conjugando novos conhecimentos com práticas vivenciadas, tais como, planejamento e gerenciamento, melhoria do produto e interação com o mercado local. Outros benefícios visualizados pelos gestores estavam associados à geração de renda e à possibilidade da conjugação das atividades domésticas com as atividades profissionais.

Nesse sentido, o PMM, baseado em sua metodologia de "Acesso, Permanência e Êxito", apresentou fragilidades em termos de interações e parcerias com outros atores/instituições, que estavam conjugadas com a ausência de políticas públicas engendradas, com ações intersetorizadas de médio e longo prazo, que abrangessem os aspectos culturais, ambientais, sociais e econômicos. Enfim, o programa focou suas ações em cursos associados à domesticidade, como alimentação e culinária, cuidador de idosos, empregada doméstica, artesanato, dentre outros. A oferta de cursos para capacitação produtiva feminina dependia, além do nível de escolaridade e experiências prévias da mulher, da disponibilidade dos recursos humanos das instituições gestores do programa, bem como do apoio do setor público, em termos de infraestrutura básica, serviços e equipamentos turísticos.

Quanto aos resultados da análise textual relacionada à trajetória de vida, evidencia-se que a maioria das mulheres teve um passado difícil, complicado, triste e sofrido, com muitas mágoas, frustrações, perdas e abandono de entes próximos, como pai e mãe; enquanto a realidade presente estava marcada por alegrias, mesmo com as dificuldades, pelo fato de estarem com os familiares, terem bens, que, anteriormente, Ihes eram negado e, principalmente, por estarem frequentando o PMM. Existiam, também, muitas expectativas quanto ao futuro, a partir dos novos conhecimentos adquiridos no programa. 
A trajetória de vida não é linear, sendo vista como integração entre o passado e o presente, marcado pela ocorrência do PMM, que representou uma bifurcação no curso da vida feminina, pelo fato de haver proporcionado elevação da autoestima, maior motivação e integração social, com mudanças em suas vidas pessoais e "sonhos" quanto ao futuro. Entretanto, a maioria das mulheres reconhece que, no cenário vivenciado, para que possa melhorar a situação presente, seria necessário arrumar emprego e, consequentemente, melhorar a situação financeira, possuir casa própria, independência, ter qualificação profissional e maior nível de escolaridade, o que, consequentemente, ampliaria a inclusão social.

Assim, se referiam ao PMM, como estratégia para "abrir portas" e melhorar as oportunidades, ao poder propiciar mais estudos, profissionalização, maiores possibilidades de inserção no mercado de trabalho e aumento da renda; além de maior integração social (contatos e novas amizades) e elevação da autoestima; enfim, melhoria da qualidade de vida.

Nesse sentido, pode-se concluir que, embora o programa seja visto como "uma maravilha" pelas mulheres, uma oportunidade de promover mudanças em suas trajetórias de vida não lineares, reconhece-se que a melhoria da situação presente exige o ingresso no mercado de trabalho, o que envolveria mais investimentos nos estudos. Ou seja, o PMM, como estratégia política educacional, por meio da sua metodologia, apresenta restrições para a qualificação das mulheres e inclusão produtiva, pois a informalidade e precariedade prevalecem no cotidiano feminino, demonstrando que a lógica da exclusão se mantém na trajetória de vida das participantes do programa; embora se sintam mais felizes e motivadas, ao serem valorizadas e com maior capacidade de integração social.

\section{REFERÊNCIAS}

ALMEIDA, Isabele Oliveira de; SALAZAR, Viviane Santos; LEITE, Yákara Vasconcelos Pereira. Processo de ensino e aprendizagem do profissional de cozinha: didática do saber técnico e o restaurante-escola. Observatório de Inovação do Turismo - Revista Acadêmica, Rio de Janeiro, v. 9, n. 1, p. 28-51, 2015. Google

ALVES, Claudia Beatriz Carrião. Programa Mulheres Mil no Câmpus Aparecida de Goiânia do Instituto Federal de Goiás: Uma possibilidade de inclusão social e acesso à educação. 2015. 134 f. Dissertação (Mestrado em Ciências Exatas e da Terra) - Pontifícia Universidade Católica de Goiás, Goiânia, 2015.

ARAÚJO, Suede Mayne Pereira. Mulheres em situação de fragilidade social e o Programa Mulheres Mil: o papel das políticas na perspectiva de emancipação para o trabalho. 2015. 152 f. Dissertação (Mestrado Profissional em Gestão e Tecnologias Aplicadas à Educação), Universidade do Estado da Bahia, Salvador, 2015. 
BANCILLON, Deco; NEGREIROS, José. "Não há outra fronteira de crescimento em ano de crise" diz ministro do Turismo. Acesso em: 19 dez. 2017. [Visualizar]

BARDIN, Laurence. Análise de conteúdo. 5. ed. Lisboa: Edições 70, 2011.

BOURDIEU, Pierre. A economia das trocas simbólicas. 5 ed. São Paulo: Perspectiva, 1998.

BRAGA, Gustavo Henrique. Turismo movimenta R\$ 492 bilhões no Brasil. Disponível em: http://www.turismo.gov.br/ultimas-noticias/957-turismo-movimenta-r-492-bilhoes-no-brasil.html Acesso em: 28 out. 2018.

BRASIL. Diretrizes nacionais para qualificação em turismo. Brasília: Ministério do Turismo, 2015.

BRASIL. Ministério da Educação e Cultura - MEC. Secretaria de Educação Profissional e Tecnológica. Guia metodológico do sistema de acesso, permanência e êxito. Brasília: SETEC, 2012.

BRASIL, Ministério da Educação. Mulheres mil na rede federal caminhos da inclusão. Brasília: Ministério da Educação, 2011, 168. Acesso em: 26 nov. 2018. [Visualizar].

CAMARGO, Brigido Vizeu; JUSTO, Ana Maria. IRAMUTEQ: um software gratuito para análise de dados textuais. Temas em Psicologia, Riberão Preto, v. 21, n. 2, p. 513-518, 2013. Google

CAMPOS, Rosa Ludy Arias.; RENGIFO, Martha Leonor Ayala; MEZA, Cristhian James Diaz. Reflexiones sobre el derecho a La educación y sus perspectivas em el marco del desarrollo humano. Revista lasallista de investigación, Caldas, v.8, n. 1, p.117-125, 2011. Google

CANOTILHO, Ana Paula; ARAUJO, Neuza Farias; OLIVEIRA, Sandra Mara Tabosa de. A contribuição da Escola para a emancipação das mulheres. Acesso em: 19 dez. 2017. [Visualizar] Google

CARBONARI, Paulo Cesar. Sujeito de direitos humanos: questões abertas em construção. In: Silveira, R. M. et. al. Educação em Direitos Humanos: Fundamentos teóricometodológicos. João Pessoa: Editora Universitária, 2007.

COELHO, André Meyer; RIBEIRO, Letícia Magno; FONTES FILHO, Joaquim Rubens. A Experiência como vantagem competitiva para o Turismo. Fundação Getúlio Vargas - FGV. Acesso em: 09 jan. 2018. [Visualizar] Google

CORCETTI, Elizabete; LORETO, Maria das Dores Saraiva de; PINTO, Neide Maria de Almeida; LICERIO, Amanda Leandro Conceição. Análise do discurso das egressas do Programa Mulheres Mil: avanços para a equidade no espaço doméstico? Caderno Espaço Feminino. Uberlândia, v. 30, n. 2, p.27-46, 2017. Ecrossef Google

CURY, Anay; SILVEIRA, Daniel. PIB recua 3,6\% em 2016, e Brasil tem pior recessão da história. Acesso em: 30 mar. 2018. [Visualizar].

DIAS, Reinaldo; MATOS, Fernanda. Políticas Públicas: princípios, propósitos e processos. São Paulo: Atlas, 2012. 
GUIMARÃES, Jaciane Pinto. Projeto de vida, deslocamentos e configurações identitária Marcas de gênero em mulheres doutoranda na UFV. 2004.114f. Dissertação (Mestrado em Economia Doméstica), Universidade Federal de Viçosa-UFV, Viçosa, 2004.

IBGE. Censo Demográfico 2010. Rio de Janeiro: IBGE, 2011. Disponível em: https://censo2010.ibge.gov.br/. Acesso em: 15 out. 2018.

LAGOS, Márcia Beralfo. "Palmas para Mulheres Mil” em comunidades quilombolas: a participação do IFPR - campus Palmas no Programa Nacional de Inclusão Social. 2014. $140 \mathrm{f}$. Dissertação (Mestrado em Desenvolvimento Regional), Universidade Tecnológica Federal do Paraná, Pato Branco, 2014.

LINS, Cyntia Freitas Melo. Apostila de Iramuteq. Fortaleza: UNIFOR, 2017 (Notas de Aula)

LUNARDI, Raquel; ALMEIDA, Joaquim Anécio de Jesus. Turismo Rural: a contribuição da mulher. RACE, Joaçaba, v. 5, n. 2, p. 157-168, 2006. Google

MACEDO, Ana Raquel. Turismo regional no Brasil: qualificação da mão de obra está entre os desafios. 30/10/2013. Disponível em http://www2.camara.leg.br/ Acesso em: 30 mar. 2018.

MENDES E SILVA, Tássia. A educação profissional e a política pública mulheres mil: a implementação no âmbito do IFMA em São Luís. 2015. 102 f. Dissertação (Mestrado em Políticas Públicas), Universidade Federal do Maranhão, São Luís, 2015.

OLIVEIRA, Maria Auxiliadora Silva Moreira. Programa Mulheres Mil no Instituto Federal de Sergipe: interfaces com a educação e o trabalho. 2013. 157 f. Dissertação (Mestrado em Serviço Social), Universidade Federal de Sergipe, Sergipe, 2013.

PIRES, Jeanine. O Turismo na Contramão. 2017. Disponível em:

http://blog.panrotas.com.br/mktdestinos/index.php/2017/03/22/o-turismo-na-contramao/. Acesso em: 31 out. 2018.

REIS, Lílian Perdigão Caixêta. Construção cultural da maternidade: a experiência de mães do Subúrbio Ferroviário de Salvador - Bahia. 2010. 227f. Tese (Doutorado em Psicologia). Universidade Federal da Bahia. Salvador, Bahia. 2010.

ROSA, Stela. Mulheres Mil: do sonho à realidade. Brasília: Ministério da Educação, 2011. Disponível em: http://mulheresmil.mec.gov.br. Acesso em: 30 out. 2018.

RIBEIRO, Letícia Érica Gonçalves. A qualificação profissional e cidadã: um estudo do Programa Mulheres Mil, a partir da experiência do Instituto Federal de Goiás, campus de Luziânia. 2013. 155 f. Dissertação (Mestrado em Educação), Universidade de Brasília, Brasília, 2013.

SILVA, Cleonice Maria da. Processos formativos na educação profissional: reflexões sobre o Programa Mulheres Mil do IFSuldeMinas. Olh@res, Guarulhos, v. 4, n. 1, p. 161-181, 2016. 
SOUZA, Ivana Carolina Alves da Silva; SILVA, Francisca de Paula Santos da. Educação Para o Turismo: Uma Análise das Práticas Pedagógicas no Ensino Fundamental. In: Encontro SE MINTUR, Saberes e Fazeres no Turismo: Interfaces, 1., 2010, Caxias do Sul. Anais [...] Universidade de Caxias do Sul, 2010. v. 1, p. 1-14. Google

VELHO, Gilberto. Individualismo e cultura: notas para uma antropologia da sociedade contemporânea. 5. ed. Rio de Janeiro: Jorge Zahar, 1999. Google

LEVY, René; GAUTHIER, Jacques-Antoine; WIDMER, Eric. Entre contraintes institutionnelle et domestique: Les parcours de vie masculins et féminins en Suisse. The Canadian Journal of Sociology / Cahiers canadiens de sociologie, v. 31, n. 4, p. 461-462, 2006. 